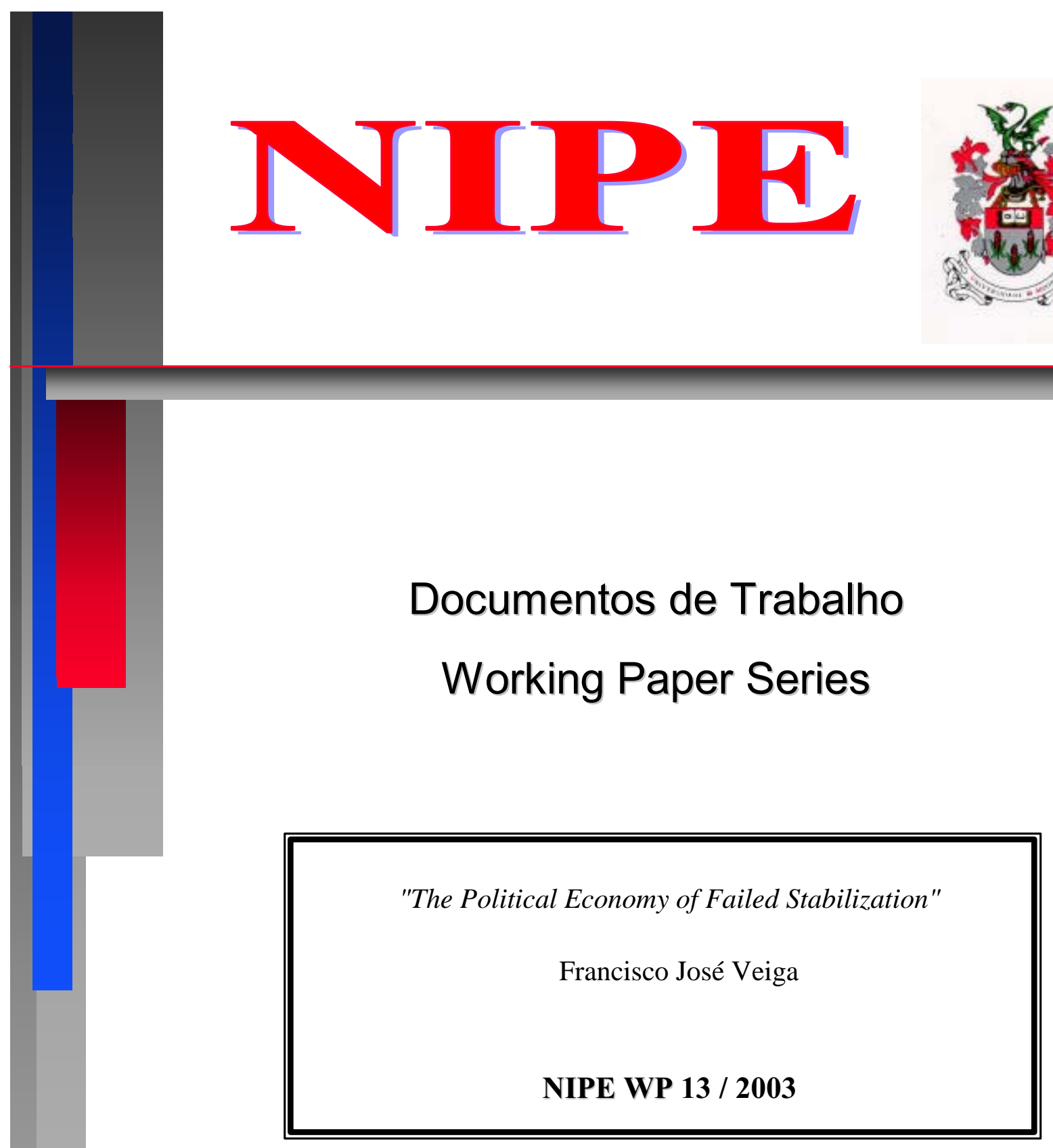

NÚCLEO DE INVESTIGAÇÃO EM POLÍTICAS ECONÓMICAS UNIVERSIDADE DO MINHO 


\title{
The Political Economy of Failed Stabilization*
}

\author{
Francisco José Veiga $^{* *}$
}

Universidade do Minho-NIPE

\begin{abstract}
This paper is an empirical analysis of the likelihood of failure of inflation stabilization programs. Logit models are estimated on a dataset of 39 programs implemented in 10 countries since the late $1950 \mathrm{~s}$, in order to determine which economic and political variables affect the probability of failure of stabilizations. Besides the well-known effects of real exchange rate appreciation, decreasing foreign reserves, budget deficits and slower GDP growth, I find that political instability, party fractionalization, less pluralism or democracy (greater autocracy), longer time in office and leftist incumbents also increase the probability of failure of inflation stabilization plans.
\end{abstract}

JEL codes: E31, E63

Keywords: Inflation stabilization, failure, political economy.

\footnotetext{
* The author wishes to express his gratitude for the financial support of the Portuguese Foundation for Science and Technology (FCT) under research grant POCTI/32491/ECO/2000 and for the research assistance of Helena Fernandes.

**Francisco José Veiga, Escola de Economia e Gestão, Universidade do Minho, P-4710-057 Braga, Portugal. Tel: +351-253604534; Fax: +351-253676375; E-mail: fjveiga@eeg.uminho.pt.
} 


\section{Introduction}

The purpose of the present paper is to study empirically the causes of failure of inflation stabilization programs implemented in countries suffering from chronic inflation. This study builds upon and complements previous research undertaken by the author (Veiga, 1999), which only considered the effects of internal macroeconomic variables on the probability of failure of a stabilization program. Although macroeconomic variables such as real exchange rates, budget deficits, foreign reserves and GDP growth are important determinants of a program's outcome, they do not explain it completely. The theoretical literature on economic policy reform suggests that political variables also play an important role. Furthermore, external financial assistance and external shocks also need to be taken into account. Thus, the empirical exercise undertaken here accounts for the possible effects of internal macroeconomic variables, assistance from the International Monetary Fund (IMF), external shocks, and political variables such as political instability, party fractionalization, pluralism/democracy, time in office, and incumbent's ideological orientation. In short, this paper is essentially an empirical study on the political economy of the outcome of inflation stabilization programs.

In order to determine which economic and political variables affect the probability of failure of a stabilization plan, random effects logit models are estimated over a sample of quarterly data for 39 programs implemented in 10 countries, since the late 1950s. Results indicate that the following lead to a higher probability of failure: real effective exchange rate appreciation, budget deficits, losses of external reserves, slower GDP growth, political instability, party fractionalization, less pluralism/democracy (greater autocracy), longer time in office, and left-wing oriented incumbents.

The paper is structured as follows. The literature on the economic and political causes of failure of inflation stabilizations is summarized in section 2. Section 3 describes the data 
and the econometric model, and section 4 describes the empirical results. Finally, section 5 concludes the paper.

\section{Economic and political causes of failure of inflation stabilization}

It is well-known that stabilizations are not all alike and that each program has specific characteristics that help explain its success or failure. Nevertheless, it is possible to identify empirical regularities associated with fighting inflation in chronic inflation countries. ${ }^{1}$ Exchange rate-based stabilizations (ERBS) are generally associated with: real appreciation of the domestic currency; deterioration of the trade balance and current account; initial increases in output and consumption followed by a slowdown; ambiguous response of domestic real interest rates; increase in real wages; failure to reduce the fiscal deficit dampens the reduction of inflation and makes real appreciation worse; and, the use of price and wage controls as an additional anchor does not seem to change the final result. Money-based stabilizations (MBS) are less common and their implications are more difficult to generalize. Nevertheless, the following stylized facts have been identified in the literature: slow convergence of inflation to the rate of monetary growth; real appreciation of the domestic currency; ambiguous behavior of the trade balance and current account; initial contraction of economic activity followed by a later expansion; initial increase in domestic real interest rates.

Dornbusch (1991) and Orphanides (1996) develop models that identify several factors that raise or lower the probability of failure of a plan. Adjustment effort, in the form of fiscal stabilization and slower money growth, and availability of foreign reserves (that are subject to stochastic shocks) are the main determinants of a plan's probability of failure. Veiga's (1999) model of balance of payments crises also shows that an ERBS may fail when the rate

\footnotetext{
${ }^{1}$ See Calvo and Végh (1994, 1999), Kiguel and Leviatan (1991, 1992), Végh (1992) and Veiga (1999).
} 
of money growth (that is determined by the budget deficit) is not consistent with a fixed exchange rate. The dynamics leading to the collapse of an ERBS involves real exchange rate appreciation, continuous depletion of foreign reserves, deteriorating trade balance and current account, and budget deficits.

External assistance from institutions like the IMF or the World Bank may also affect a program's probability of failure (see Orphanides, 1996). By providing additional external reserves that help sustain a fixed exchange rate or a crawling peg, external assistance may contribute to the success of an ERBS. But, if the funding is used to reduce the adjustment effort, the probability of failure may not change or may even increase.

A program's final outcome can also be affected by external shocks. Increasing oil prices worsen the trade balance and the current account of oil importing countries, leading to a faster depletion of reserves. Higher international interest rates increase the cost of external funding and create pressure for the depreciation of the national currency, which may precipitate the failure of an ERBS. Finally, slower GDP growth abroad reduces the demand for a country's exports, which worsens external accounts and GDP growth, possibly increasing the probability of failure of stabilization programs.

Although the economic variables referred to above are important determinants of the success or failure of inflation stabilization programs, they do not explain them completely. The theoretical literature on economic policy reform suggests that several political variables should also be taken into account. In Alesina and Drazen's (1991) model, a lower degree of social cohesion or greater degrees of political polarization and fragmentation lead to greater delays of the implementation of successful stabilization programs ${ }^{2}$ (which are generally

\footnotetext{
${ }^{2}$ Empirical support for their model is provided by Veiga (2000), who shows that higher fragmentation of the government or of the parliament lead to greater delays in the implementation of stabilization programs in situations of high inflation.
} 
preceded by several failed attempts). According to Cukierman, Edwards and Tabellini (1992), countries with more unstable and polarized political systems will have more inefficient tax structures and will rely more heavily on seigniorage. Thus, these models suggest that variables related to political instability, polarization and social cohesion should be included in an empirical analysis of the likelihood of successful stabilization.

Haggard and Kaufman (1992) argue that the security of governments and their independence from the short-run distributive political pressures has great effects on the level and variability of inflation over the long run. Furthermore, governments in less fragmented political systems, such as authoritarian regimes, are less exposed to those political pressures and need not waste time and energy building consensus for reform. Thus, stabilization programs may be easier to implement in authoritarian regimes.

The political business cycles literature suggests that time in office and ideological orientation of incumbents can also affect a plan's probability of failure. Opportunistic politicians (Nordhaus, 1975) are more inclined to implement the tough and unpopular measures necessary for the success of stabilizations in the beginning of their terms. Thus, failure is more likely to happen as time in office increases. According to Hibbs' (1977) partisan model, right-wing oriented incumbents care relatively more about inflation that leftwing ones. This implies that success is more likely for right-wing governments, as these are more willing to make the necessary sacrifices to bring down inflation.

\section{The data and the econometric model}

The first major issue to consider when constructing the dataset was to determine when a stabilization program had been implemented. The method consisted in searching the economics literature for information on the dates of implementation and failure/abandonment of stabilization programs undertaken in countries suffering from chronic inflation. The 44 
stabilizations identified are described in Table 1. In that table, the starting and ending quarters, the type, and the main sources for identifying each stabilization plan are also indicated. The plans that are more often referred to in the literature and that represented the most serious attempts at reducing inflation (the "Major Stabilizations") appear in bold.

\section{$<<$ Insert Table 1 around here $>>$}

As previously stated, the objective of the present paper is to analyze how the probability of failure of a stabilization program depends on a set of economic and political variables. For that purpose, a separate observation for each quarter was created in which each plan was observed from implementation until failure, or censoring. Thus, each plan contributed a number of observations equal to its duration in quarters. For each quarter, and each plan, the dependent variable $(F A I L)$ takes the value of one if the stabilization program failed in that quarter, and zero otherwise. If a plan did not fail, FAIL takes the value of zero for all observations of that plan.

Since some stabilizations did not last more than one quarter, their causes of failure cannot be accurately analyzed with quarterly data. For that reason, three plans described in Table 1 where not considered in the dataset (Primavera $I$ and $B B$, in Argentina, and the Gradualist plan, in Brazil) and another three where classified as a single program (Package Deals I, II and III, in Israel). Thus, the dataset used in the empirical analysis includes 39 stabilizations.

The second major issue concerning the construction of the dataset was to determine when a program that did not fail should be censored. One possibility would be to do it in the last quarter covered by the dataset, that is, in the fourth quarter of 2000. Instead, stabilizations were censored after five years of successful implementation. Here, I followed 
Calvo and Végh (1994), who arbitrarily set to five years the duration of the programs that had not failed in a shorter period of time. That is, after five years (20 quarters) of successful implementation, a program is considered a success and is no longer observed. The reason for not censoring plans in the fourth quarter of 2000 is that the horizon after stabilization would be so long that macroeconomic performance in the final years would be essentially unrelated to the stabilization program under analysis. ${ }^{3}$ A five-year horizon avoids that problem and is long enough to thoroughly analyze each program. Furthermore, it produces little changes in the programs' final outcomes. ${ }^{4}$

In order to identify the economic and political variables that affect the probability of failure of a stabilization plan, a binary logit model was estimated, controlling for program specific random effects. ${ }^{5}$ I hypothesize that the unobserved hazard rate depends on the following explanatory variables:

- A set of internal macroeconomic variables: ${ }^{6}$

- Reer - Accumulated real effective exchange rate depreciation against the 10 main trading partners since the beginning of stabilization. Higher values correspond to greater competitiveness, which improves the trade balance and should reduce the probability of failure;

- TR - Quarterly percentage change in total reserves. An increase in reserves facilitates the implementation of an ERBS, and should thus decrease its probability of failure;

\footnotetext{
${ }^{3}$ In the cases of the Bolivian and Israeli plans implemented in 1985, almost 15 years of data would be included if these programs were censored only in the fourth quarter of 2000.

${ }^{4}$ Of the stabilizations that failed until 2000, only 3 lasted more that 5 years.

${ }^{5}$ Controlling for fixed effects of programs is not possible because there are several stabilizations that do not fail: the dependent variable, FAIL, is equal to zero for all observations of these programs.

${ }^{6}$ These are the variables considered in Veiga (1999), with the exception that I now use real effective exchange rate depreciation instead of the real exchange rate appreciation against the US dollar.
} 
- TR/Imp - Ratio of Total Reserves to Imports. A greater stock of reserves also decreases the probability of failure of an ERBS;

- FB/GDP - Fiscal Balance (Government Budget Balance) as a percentage of $G D P$. Smaller budget deficits or greater surpluses are essential to the success of a stabilization. Thus, a negative coefficient is expected;

- GDP - Growth of real GDP since the same quarter of the previous year. Higher economic growth reduces the costs of stabilization and thus contributes to its success;

- $C A / G D P-C u r r e n t$ Account balance as a percentage of GDP. Improvements in external accounts lead to gains of reserves and reduce the probability of failure of stabilization plans;

- Variables representing external assistance and external shocks:

- IMF - Ongoing IMF arrangement. Financial assistance from the IMF can reduce the costs of a stabilization plan and thus contribute its success;

- OIL - Index for the change in the price of oil since the beginning of the stabilization. Higher oil prices make the reduction of inflation harder and thus increase a plan's probability of failure;

○ US_TBill - U.S. Treasury Bill rate. Higher international interest rates increase the costs of obtaining funds abroad and can contribute to a plan's failure;

○ GDP_TP - GDP growth of trading partners. Higher growth of trading partners increases exports and could contribute to a plan's success;

- A set of political variables: 
- GCrises - Number of government crises since the beginning of the stabilization program. This variable is the main proxy for political instability, which should increase the probability of failure of a stabilization;

- FracInd - Party fractionalization index. Higher values are associated with a larger number of parties represented in parliament, higher political polarization, and greater difficulty to approve the tough measures necessary for the success of a stabilization (a positive coefficient is expected);

- CompInd - Composite legislature index. Higher values are associated with greater effectiveness of the legislature, political pluralism and freedom. According to Haggard and Kaufman (1992), greater democracy increases a plan's probability of failure;

- QLCH - Quarters since the last change in government or election. Incumbents are expected to implement the toughest measures in the beginning of their terms (when $Q L C H$ is small). Thus, a positive coefficient is expected;

- Right - Right or center-right oriented government. According to Hibbs (1977), rightist parties care relatively more about inflation than leftist ones. Thus, we expect a negative coefficient for this variable.

All variables used in the empirical analysis, their sources, and the expected signs of the coefficients associated with the explanatory variables are described in table $2 .^{7}$

$<<$ Insert Table 2 around here $>>$

\footnotetext{
${ }^{7}$ For some countries, only annual data are found on some variables, especially for earlier decades (1950s and 1960 s). The variables for which interpolation was used to generate quarterly values are: $G D P, F B / G D P$, $C A / G D P$ and GDP TP. Other interpolation methods such as "cubic mach last" of Eviews 4.1, were tried, but empirical results are virtually the same regardless of the method used.
} 


\section{Empirical results}

The results of logit models estimations are presented in Table 3. Since logit coefficients $(\beta)$ are not easily interpretable, odds ratios $\left(e^{\beta}\right)$ are reported in brackets. These can be interpreted as follows: for a unit change in the explanatory variable $x_{k}$, the odds are expected to change by a factor of $\exp \left(\beta_{k}\right)$, holding all other variables constant. The pseudo- $\mathrm{R}^{2}$ (or McFadden $\mathrm{R}^{2}$ ), the percentage of correct predictions, and the number of observations, failures and programs are indicated at the foot of the table.

\section{$<<$ Insert Table 3 around here $>>$}

In column 1 only the set of internal macroeconomic variables is used, so that results can be easily compared to those of Veiga (1999). All variables except the change in reserves, $T R,{ }^{8}$ were lagged one period in order to account for simultaneity problems. Real effective exchange rate depreciation (Reer), budget surpluses $(F B / G D P)$, increasing reserves $(T R)$ and higher GDP growth $(G D P)$ reduce the probability of failure of a stabilization program, while the stock of reserves $(T R / \operatorname{Imp})$ and the current account balance as a percentage of GDP $(C A / G D P)$ do not seem to matter. Except for these last two variables, results are in line with those of Veiga (1999). Although the pseudo- $\mathrm{R}^{2}$ is relatively low (0.17), the percentage of correct predictions is quite high (93\%). Results remain the same when $T R / \operatorname{Imp}$ and $C A / G D P$ are excluded from the model (column 2).

The model of column 3 adds a set of external assistance and external shocks variables to the estimation of column 2. While increasing oil prices since the beginning of the stabilization, $O I L$, increase the latter's probability of failure, IMF arrangements $(I M F)$, U.S.

\footnotetext{
${ }^{8} T R$ was not lagged because the big drops in reserves that often lead to the impossibility of maintaining an ERBS tend to happen in the quarter of failure and not before.
} 
Treasury Bill rates $\left(U S \_T B i l l\right)$ and GDP growth of trading partners $\left(G D P \_T P\right)$ do not seem to affect that probability. ${ }^{9}$ Results regarding the effect of oil prices and the absence of effects of IMF assistance are in line with the findings of Ball and Rausser (1995), but results regarding the last two variables diverge from those of Hamann and Prati (2002) who found statistically significant effects of US interest rates and external demand.

In the estimation of column 4 , the variables that were statistically significant in column 3 are used together with a set of political variables. TR and $O I L$ are no longer statistically significant and all political variables are significant and have the expected signs. Political instability (more government crises - GCrises) ${ }^{10}$ and party fractionalization (FracInd) are positively related to the probability of failure, as suggested by the models of Alesina and Drazen (1991) and Cukierman, Edwards and Tabellini (1992). A greater degree of pluralism (CompInd) reduces that probability, contradicting Haggard and Kaufman (1992), who suggested that authoritarian regimes deal better with inflation reduction. ${ }^{11}$ Longer time in office $(Q L C H)$ and leftist orientation of incumbents $($ Right $=0)$ increase the probability of failure of stabilizations. This provides some evidence in favor of the hypotheses that opportunistic incumbents do not which to implement tough measures towards the end of their terms (Nordhaus, 1975), and that right-wing parties/incumbents care relatively more about inflation than left-wing ones (Hibbs, 1977). These results are maintained in the estimation of column 5 in which $O I L$ was not included. The only changes are that $T R$ becomes statistically significant again and GCrises is more significant.

\footnotetext{
${ }^{9} I M F$ was lagged one period in order to avoid simultaneity problems. That is, IMF assistance could arrive in the quarter of failure as a last attempt to avoid that outcome.

${ }^{10}$ GCrises was also lagged one period in order to avoid simultaneity problems. That is, a government crisis could result from the failure of a stabilization program.

${ }^{11}$ These findings concerning the effects of political instability and democracy/pluralism are in line with those obtained by Ball and Rausser (1995), for inflation reduction, and by Dollar and Svensson (2000), for the success or failure of structural adjustment programs supported by the World Bank.
} 
Comparing the results of columns 2 and 5, we can see that adding the set of political variables increases the pseudo- $\mathrm{R}^{2}$ by $11 \%$ and the percentage of correct predictions by 0.7 . The effect of some of these variables on the probability of failure is considerable. For example, an additional government crisis is expected to change that probability by a factor of 1.42, holding all other variables constant (equivalent to an increase of $42 \%$ ).

Table 4 presents the results of a series of robustness tests that essentially consist in using available alternatives to the political variables referred to above. When the average number of government crises in a given quarter, Govcrise, or the sum of cabinet changes since the start of stabilization, CabChanges, are used instead of the sum of government crises since the beginning of the stabilization (GCrises), there is still evidence in favor of the hypothesis that political instability is positively related to the probability of failure (see columns 1 and 2). Military dictatorships or authoritarian governments backed by the military $($ Type $=1)$ and greater levels of autocracy $($ Polity $<-5=1)$ are associated with greater probabilities of failure (columns 3 and 4). Thus, when CompInd is replaced by any of these variables, there is still evidence that dictatorships/autocracies are bad for stabilization. Regarding the other political variables, FracInd and $Q L C H$ are not statistically significant in 3 and 2 estimations, respectively. Thus, there is weaker evidence that greater fractionalization and time in office increase the probability of failure of a stabilization program.

\section{$<<$ Insert Table 4 around here $>>$}

The estimation of column 5 allows the probability of failure to be affected by the passage of time: the variable Dur_prog, that equals the number of quarters that have passed since the start of the stabilization, was added to the estimation of column 5 of Table 3 . 
Although the sign of the estimated coefficient indicates that programs are more likely to fail the longer they are in place, the variable is not statistically significant. ${ }^{12} 13$

Sensitivity analysis to alternative samples is reported in Table 5. All estimations use the same explanatory variables as that of column 5 of Table 3 . In column 1, programs are still censored after five years of successful implementation (5-Year Limit), but only the 23 "Major Programs" are considered (those that appear in bold in Table 1). The signs of the coefficients remain the same but $T R, G D P$ and $Q L C H$ are not statistically significant. Nevertheless, most of our conclusions regarding the effects of political variables remain the same. In the second and third estimations, programs were censored only after seven years of successful implementation. Results are almost the same than those obtained for the 5-year limit. ${ }^{14}$ The major difference is that FracInd is not statistically significant in the estimation for all programs. ${ }^{15}$

Finally, I estimated the models censoring in the fourth quarter of 2000 the programs that had not failed until then. As previously stated, this implies considering almost 15 years of observations for the Bolivian and Israeli plans of 1985 and at least 9 years of observations for the other programs that were still under implementation in 2000. Using long horizons after stabilization has the problem that the inflationary performance in the last years of observations has little relation with the stabilization program that one wishes to analyze. Although results concerning economic variables present little changes, those for political

\footnotetext{
${ }^{12}$ When using dummy variables for each year of implementation instead of Dur_Prog there is still no evidence of time effects. These, and other results not shown here, are available from the author upon request.

13 Additional robustness tests not reported here were performed. They revealed that initial inflation and the nominal anchor chosen do not affect the probability of failure, and that adding economic variables such as exports, imports, debt service, domestic credit, and openness to trade does not significantly change the results.

${ }^{14}$ Compare the estimation for all programs with that of column 5 of Table 3 and the one for Major Programs with the first estimation of Table 5 .

${ }^{15}$ Results of estimations using 4-year and 6-year limits are very similar.
} 
variables are weaker. Since GCrises was not statistically significant, ${ }^{16}$ it was replaced by Govcrise, which is significant, providing evidence that higher political instability increases the probability of failure. Of the other political variables, only the ideological orientation seems to matter. Rightist governments $($ Right $=1)$ are associated with a smaller probability of failure in the estimation for all programs.

\section{Conclusions}

This paper analyzed empirically the effects of economic and political variables on the probability of failure of inflation stabilization programs implemented in 10 countries since the late 1950s. Results regarding macroeconomic variables revealed that real effective exchange rate appreciation, higher budget deficits, loss of foreign exchange reserves and slower GDP growth contribute to the failure of stabilization attempts. These results are consistent with those of previous research undertaken by the author (Veiga, 1999) and with the stylized facts of stabilizations identified in the literature.

The main contribution of the present study is to clearly show that political factors are also very important determinants of the success or failure of stabilization programs. There is empirical evidence that political instability, party fractionalization, autocracy (less pluralism or democracy), longer time in office and left-wing ideological orientation of incumbents lead to higher probabilities of failure of stabilization attempts. These results are consistent with the models of Alesina and Drazen (1991) and Cukierman, Edwards and Tabellini (1992), according to which political instability, polarization and fragmentation are detrimental to stabilization. The hypothesis that authoritarian regimes are more capable of reducing inflation because they can resist better to political pressures (see Haggard and Kaufman,

\footnotetext{
${ }^{16}$ When a longer horizon is used, a greater number of government crises may occur during a stabilization program even if political instability is not high. Thus, this variable may not adequately proxy political instability when we use many years of observations for each program.
} 
1992), is not supported. In fact, my results indicate exactly the opposite: more plural and democratic regimes are associated with lower probabilities of failure of stabilizations. Thus, although authoritarian regimes start stabilization programs faster in the presence of high inflation, as shown by Veiga (2000), they are not more capable to conclude them successfully.

The effects of external assistance and shocks were also analyzed. Results indicate that IMF arrangements, U.S. interest rates and GDP growth of trading partners do not affect a program's probability of failure. Although increasing oil prices appear to be detrimental to stabilization when only economic variables are considered, they are not statistically significant when political variables are also included in the set of explanatory variables. Finally, initial inflation and the nominal anchor chosen do not affect a program's probability of failure. 


\section{References}

Agénor, Pierre-Richard and Peter J. Montiel, 1999. Development Macroeconomics. $2^{\text {nd }}$ ed. (Princeton University Press, New Jersey).

Alesina, A. and A. Drazen, 1991, "Why are stabilizations delayed?" American Economic Review 81(5), 1170-1188.

Ball, Richard and Gordon Rausser, 1995. "Governance structures and the durability of economic reforms: Evidence from inflation stabilizations." World Development 23(6), 897-912.

Banks, Arthur, ed. Political Handbook of the World (McGraw-Hill, New York, NY) various issues.

Calvo, Guillermo A. and Carlos A. Végh, 1994. "Inflation stabilization and nominal anchors." Contemporary Economic Policy 12, 35-45.

Calvo, Guillermo A. and Carlos A. Végh, 1999. "Inflation stabilization and BOP crises in developing countries." in Taylor, J.B. and M. Woodford, eds. Handbook of Macroeconomics, Vol. 1, (Elsevier, Holland), 1531-1614.

Cukierman, Alex, Sebastian Edwards, and Guido Tabellini, 1992, "Seigniorage and political instability." American Economic Review 82(3), 537-555.

Diaz, Francisco G. and Raul R. Tercero, 1988. “Lessons from Mexico.” In Bruno, Michael, et al., eds., 1988. Inflation Stabilization: The Experience of Israel, Argentina, Brazil, Bolivia, and Mexico. (MIT Press, Cambridge, MA), 361-390.

Dollar, David and Jakob Svensson, 2000. "What explains the success or failure of structural adjustment programmes?" The Economic Journal 110(October), 894-917.

Dornbusch, Rudiger, 1991. "Credibility and stabilization.” Quarterly Journal of Economics, August, 837-850. 
Haggard, Stephan and Robert R. Kaufman, 1992. "The Political Economy and Stabilization in Middle-Income Countries.” In: Haggard, Stephan and Robert R. Kaufman, eds., The Politics of Economic Adjustment (Princeton University Press, NJ), 270-315.

Hamann, Javier and Alessandro Prati, 2002. "Why do many disinflations fail? The importance of luck, timing, and political institutions." IMF Working paper $W P / 02 / 228$.

Heyman, Daniel, 1991. "From sharp disinflation to hyperinflation, twice: the Argentine experience, 1985-1989.” In Bruno, Michael, et al., eds., 1991. Lessons of Economic Stabilization and its Aftermath. (MIT Press, Cambridge, MA), 103-130.

Hibbs, Douglas, 1977. "Political Parties and Macroeconomic Policy." American Political Science Review 71, 1467-1487.

Hoffmaister, Alexander W. and Carlos A. Végh, 1996. "Disinflation and the Recession-NowVersus-Recession-Later Hypothesis: Evidence from Uruguay." IMF Staff Papers 43(2), 355-394.

IMF, Annual Report (International Monetary Fund, Washington D.C.), several issues.

Kiguel, Miguel and Nissan Leviatan, 1988. "Inflationary Rigidities and Stabilization Policies." World Bank Working Paper WPS-4, April.

Kiguel, Miguel and Nissan Leviatan, 1991. "The Inflation-Stabilization Cycles in Argentina and Brazil.” In Bruno, Michael, et al., eds., 1991. Lessons of Economic Stabilization and its Aftermath. (MIT Press, Cambridge, MA), 191-232.

Kiguel, Miguel and Nissan Leviatan, 1992. "The Business Cycle Associated with Exchange Rate-Based Stabilizations.” The World Bank Economic Review 6(2), 279-305.

Orphanides, Athanasios, 1996, "The timing of stabilizations." Journal of Economics Dynamics \& Control 20(1-3), 257-279. 
Morales, Juan A., 1988. "Inflation stabilization in Bolivia.” In Bruno, Michael, et al., eds., 1988. Inflation Stabilization: The Experience of Israel, Argentina, Brazil, Bolivia, and Mexico. (MIT Press, Cambridge, MA), 307-346.

Nordhaus, William, 1975. “The Political Business Cycle.” Review of Economic Studies 42, 169-190.

Razin, Assaf, 1991. "The Inflation-Stabilization Cycles in Argentina and Brazil: Comments by Assaf Razin.” In Bruno, Michael, et al., eds., 1991. Lessons of Economic Stabilization and its Aftermath. (MIT Press, Cambridge), MA, 235-238.

Rodrik, Dani, 1991. "Premature liberalization, incomplete stabilization: the Özal decade in Turkey.” In Bruno, Michael, et al., eds., 1991. Lessons of Economic Stabilization and its Aftermath. (MIT Press, Cambridge, MA), 323-353.

Végh, Carlos A., 1992. "Stopping High Inflation: An Analytical Overview." IMF Staff Papers 39(3), 626-695.

Veiga, Francisco José, 1999. "What causes the failure of inflation stabilization plans?" Journal of International Money and Finance 18(2), 169-194.

Veiga, Francisco José, 2000. "Delays of Inflation Stabilizations." Economics and Politics 12(3), 275-295.

World Europa Yearbook (Europa, London, UK) several issues. 
Table 1: Stabilization Programs

\begin{tabular}{|c|c|c|c|}
\hline Country & Program dates/names & Type & Main Sources \\
\hline Argentina & $\begin{array}{l}\text { 1958:4 - 1959:2 } \\
\text { 1959:3 - 1962:2 } \\
\text { 1967:1 - 1970:2 } \\
\text { 1973:3 - 1975:2 } \\
\text { 1976:2 - 1978:3 } \\
\text { 1978:4 - 1981:2 (Tablita) } \\
\text { 1985:2 - 1986:3 (Austral I) } \\
\text { 1986:3 - 1986:4 (Primavera I) } \\
\text { 1987:1 - 1987:2 (February) } \\
\text { 1987:4 - 1988:2 (Austral II) } \\
\text { 1988:3 - 1989:1 (Primavera II) } \\
\text { 1989:3 - 1989:4 (BB) } \\
\text { 1989:4 - 1991:1 (Bonex) } \\
\mathbf{1 9 9 1 : 2 ~ - ~ 2 0 0 2 : 1 ~ ( C o n v e r t i b i l i t y ) ~}\end{array}$ & $\begin{array}{l}\text { MBS } \\
\text { ERBS } \\
\text { ERBS } \\
\text { ERBS } \\
\text { MBS } \\
\text { ERBS } \\
\text { ERBS } \\
\text { ERBS } \\
\text { ERBS } \\
\text { ERBS } \\
\text { ERBS } \\
\text { ERBS } \\
\text { MBS } \\
\text { ERBS }\end{array}$ & $\begin{array}{l}\text { Kiguel and Leviatan (1988) } \\
\text { Kiguel and Leviatan (1992) } \\
\text { Kiguel and Leviatan (1992) } \\
\text { Kiguel and Leviatan (1992) } \\
\text { Kiguel and Leviatan (1988) } \\
\text { Kiguel and Leviatan (1992) } \\
\text { Kiguel and Leviatan (1991) } \\
\text { Kiguel and Leviatan (1991) } \\
\text { Kiguel and Leviatan (1991) } \\
\text { Kiguel and Leviatan (1991) } \\
\text { Kiguel and Leviatan (1991) } \\
\text { Heyman (1991) } \\
\text { Calvo and Vegh (1999) } \\
\text { Calvo and Vegh (1999) }\end{array}$ \\
\hline Bolivia & $\begin{array}{l}\text { 1982:4 - 1983:4 } \\
\text { 1984:2 - 1984:3 } \\
\text { 1985:1 - 1985:2 } \\
\text { 1985:3 - present }\end{array}$ & $\begin{array}{l}\text { ERBS } \\
\text { ERBS } \\
\text { ERBS } \\
\text { ERBS }\end{array}$ & $\begin{array}{l}\text { Morales (1988) } \\
\text { Morales (1988) } \\
\text { Morales (1988) } \\
\text { Morales (1988), Végh (1992) }\end{array}$ \\
\hline Brazil & $\begin{array}{l}\text { 1964:1 - 1968:3 } \\
\text { 1986:1 - 1986:4 (Cruzado) } \\
\text { 1987:2 - 1988:1 (Bresser) } \\
\text { 1988:2 - 1988:2 (Gradualist) } \\
\text { 1989:1 - 1989:3 (Summer) } \\
\text { 1990:1 - 1991:1 (Collor) } \\
\text { 1994:3 - 1999:1 (Real) }\end{array}$ & $\begin{array}{l}\text { ERBS } \\
\text { ERBS } \\
\text { ERBS } \\
\text { ERBS } \\
\text { ERBS } \\
\text { MBS } \\
\text { ERBS }\end{array}$ & $\begin{array}{l}\text { Calvo and Vegh (1999) } \\
\text { Kiguel and Leviatan (1991) } \\
\text { Kiguel and Leviatan (1991) } \\
\text { Kiguel and Leviatan (1991) } \\
\text { Kiguel and Leviatan (1991) } \\
\text { Calvo and Vegh (1999) } \\
\text { Ágénor and Montiel (1999) }\end{array}$ \\
\hline Chile & $\begin{array}{l}\text { 1975:2 - 1977:4 } \\
\text { 1978:1 - 1982:2 (Tablita) }\end{array}$ & $\begin{array}{l}\text { MBS } \\
\text { ERBS }\end{array}$ & $\begin{array}{l}\text { Calvo and Vegh (1999) } \\
\text { Calvo and Vegh (1999) }\end{array}$ \\
\hline Dominican Republic & 1990:3 - present & MBS & Calvo and Vegh (1999) \\
\hline Israel & $\begin{array}{l}\text { 1980:4 - 1982:3 (Aridor I) } \\
\text { 1982:3 - 1983:3 (Aridor II) } \\
\text { 1983:4 - 1984:2 (Cohen-Orgad) } \\
\text { 1984:3 - 1984:3 (Package Deal I) } \\
\text { 1984:4 - 1985:1 (Package Deal II) } \\
\text { 1985:1 - 1985:2 (Package Deal III) } \\
\text { 1985:3 - present (Shekel) }\end{array}$ & $\begin{array}{l}\text { ERBS } \\
\text { ERBS } \\
\text { ERBS } \\
\text { ERBS } \\
\text { ERBS } \\
\text { ERBS } \\
\text { ERBS }\end{array}$ & $\begin{array}{l}\text { Razin }(1991) \\
\text { Razin }(1991) \\
\text { Razin }(1991) \\
\text { Razin (1991) } \\
\text { Razin (1991) } \\
\text { Razin (1991) } \\
\text { Calvo and Vegh (1999) }\end{array}$ \\
\hline Mexico & $\begin{array}{l}\text { 1976:4 - 1982:1 } \\
\text { 1987:4 - 1994:4 }\end{array}$ & $\begin{array}{l}\text { ERBS } \\
\text { ERBS }\end{array}$ & $\begin{array}{l}\text { Diaz and Tercero (1988) } \\
\text { Calvo and Vegh (1999) }\end{array}$ \\
\hline Peru & $\begin{array}{l}\text { 1985:3 - 1988:3 } \\
\text { 1990:3 - present }\end{array}$ & $\begin{array}{l}\text { ERBS } \\
\text { MBS }\end{array}$ & $\begin{array}{l}\text { Agénor and Montiel (1999) } \\
\text { Calvo and Vegh (1999) }\end{array}$ \\
\hline Turkey & 1980:1 - 1987:4 & MBS & Rodrik (1991) \\
\hline Uruguay & $\begin{array}{l}\text { 1960:4 - 1963:2 } \\
\text { 1968:2 - 1971:4 } \\
\text { 1978:4 - 1982:4 (Tablita) } \\
\text { 1990:4 - present }\end{array}$ & $\begin{array}{l}\text { MBS } \\
\text { ERBS } \\
\text { ERBS } \\
\text { ERBS }\end{array}$ & $\begin{array}{l}\text { Hoffmaister and Vegh (1996) } \\
\text { Calvo and Vegh (1999) } \\
\text { Calvo and Vegh (1999) } \\
\text { Calvo and Vegh (1999) }\end{array}$ \\
\hline
\end{tabular}

Notes: - ERBS - Exchange Rate-Based Stabilization; MBS - Money-Based Stabilization.

- The programs whose date/name appears in bold are considered "Major Stabilizations". 
FAIL $=1$ if a stabilization program fails in the current quarter; $\quad$ (Sources: see Table 1) $=0$ otherwise.

\section{Independent Economic variables:}

Reer-Accumulated real effective exchange rate depreciation against the 10 main trading partners since the beginning of the stabilization: index number that takes the value of 100 for the first observation available (IFS and DOTS).

$T R$ - Percentage quarterly change in total reserves (IFS).

$T R / I M P$ - Total reserves as a percentage of imports (IFS).

$F B / G D P$ - Fiscal Balance (Government Budget Balance) as a percentage of GDP (IFS).

$C A / G D P$ - Current Account balance as a percentage of GDP (IFS).

$G D P$ - Growth of Real GDP since the same quarter of the previous year (IFS, IBGE and INEGI).

$I M F=1$ if there is an ongoing IMF program/arrangement, and $=0$ otherwise (IMF Annual Report and IMF Webpage).

$O I L$ - Index for the change in the price of oil since the beginning of the stabilization (OECD).

US_TBill - U.S. Treasury Bill rate (IFS).

$G D P_{-} T P$ - Annual GDP growth of trading partners (WDI and DOTS).

Dur_Prog - Number of quarters since the beginning of the stabilization program (Table 1).

\section{Independent political variables:}

GCrises - Number of government crises since the beginning of the stabilization program. A government crisis is any rapidly developing situation that threatens to bring the downfall of the present regime - excluding situations of revolt aimed at such overthrow (CNTS).

Govcrise - Average number of government crises in the current quarter (the value for the current year divided by 4$)$. (CNTS)

CabChanges - Number of cabinet changes since the beginning of the stabilization program. Refers to the number of times in which a new premier is named and/or $50 \%$ of the cabinet posts are occupied by new ministers. (CNTS)

FracInd - Party Fractionalization index $=1 / \sum t_{i}^{2}$, where $t_{i}$ is the proportion of members associated with the $i^{\text {th }}$ party in the lower house of the legislature (transformation of the variable included in the CNTS).

CompInd - Composite Legislature Index: simple, non-factorial, measure of political pluralism (CNTS).

Polity<-5 - High autocracy: $=1$ if the Polity score is below -5 , and $=0$ otherwise. The variable Polity was taken from the Polity IV Database.

Type - Type of regime: $=1$ for a military dictatorship or an authoritarian government backed by the military, and $=0$ otherwise.

$Q L C H$ - Number of quarters since the last change in government or elections.

Right $=1$ for a right or center-right oriented government, and $=0$ otherwise.

Sources (presented in parenthesis):

- IFS: International Financial Statistics - IMF; DOTS: Direction of Trade Statistics - IMF; WDI: World Development Indicators - World Bank; CNTS: Cross National Time Series Data Archive;

- Type, QLCH and Right: Banks, ed., Political Handbook of the World, several issues; Haggard and Kaufman (1992); and World Europa Yearbook, several issues. 
Table 3: Logit Models Results

\begin{tabular}{|c|c|c|c|c|c|}
\hline & 1 & 2 & 3 & 4 & 5 \\
\hline $\operatorname{Reer}(-1)$ & $\begin{array}{c}-.017 \\
{[.98]} \\
(-2.33)^{* *}\end{array}$ & $\begin{array}{c}-.015 \\
{[.99]} \\
(-2.34)^{* *}\end{array}$ & $\begin{array}{c}-.015 \\
{[.98]} \\
(-2.01)^{* *}\end{array}$ & $\begin{array}{c}-.023 \\
{[.98]} \\
(-2.01)^{* *}\end{array}$ & $\begin{array}{c}-.022 \\
{[.98]} \\
(-1.94)^{*}\end{array}$ \\
\hline$F B / G D P(-1)$ & $\begin{array}{c}-.125 \\
{[.88]} \\
(-3.99)^{* * *}\end{array}$ & $\begin{array}{c}-.114 \\
{[.89]} \\
(-4.11)^{* * *}\end{array}$ & $\begin{array}{c}-.154 \\
{[.86]} \\
(-4.06)^{* * *}\end{array}$ & $\begin{array}{c}-.176 \\
{[.84]} \\
(-4.23)^{* * *}\end{array}$ & $\begin{array}{c}-.176 \\
{[.84]} \\
(-4.25)^{* * *}\end{array}$ \\
\hline$T R$ & $\begin{array}{c}-.018 \\
{[.98]} \\
(-2.28)^{* *}\end{array}$ & $\begin{array}{c}-.018 \\
{[.98]} \\
(-2.34)^{* *}\end{array}$ & $\begin{array}{c}-.017 \\
{[.98]} \\
(-2.08)^{* *}\end{array}$ & $\begin{array}{c}-.016 \\
{[.98]} \\
(-1.62)\end{array}$ & $\begin{array}{c}-.017 \\
{[.98]} \\
(-1.86)^{*}\end{array}$ \\
\hline$T R / I M P(-1)$ & $\begin{array}{l}-.057 \\
{[.94]} \\
(-.27)\end{array}$ & & & & \\
\hline$G D P(-1)$ & $\begin{array}{c}-.107 \\
{[.90]}\end{array}$ & $\begin{array}{c}-.108 \\
{[.90]} \\
(-256) * *\end{array}$ & $\begin{array}{c}-.125 \\
{[.88]} \\
(-272) * * *\end{array}$ & $\begin{array}{c}-.110 \\
{[.90]} \\
(-2.25)^{* *}\end{array}$ & $\begin{array}{l}-.111 \\
{[.90]}\end{array}$ \\
\hline$C A / G D P(-1)$ & $\begin{array}{c}.074 \\
{[1.07]} \\
(.89)\end{array}$ & & & & \\
\hline $\operatorname{IMF}(-1)$ & & & $\begin{array}{c}-.251 \\
{[.78]} \\
(.60)\end{array}$ & & \\
\hline OIL & & & $\begin{array}{c}.015 \\
{[1.02]} \\
(2.25)^{* *}\end{array}$ & $\begin{array}{l}-.001 \\
{[1.00]} \\
(-.09)\end{array}$ & \\
\hline US_TBill & & & $\begin{array}{c}-.173 \\
{[.84]} \\
(-1.54)\end{array}$ & & \\
\hline$G D P \_T P$ & & & $\begin{array}{c}.214 \\
{[1.24]} \\
(1.25) \\
\end{array}$ & & \\
\hline GCrises (-1) & & & & $\begin{array}{c}.346 \\
{[1.41]} \\
(1.90)^{*}\end{array}$ & $\begin{array}{c}.353 \\
{[1.42]} \\
(2.05)^{* *}\end{array}$ \\
\hline FracInd & & & & $\begin{array}{c}.399 \\
{[1.49]} \\
(1.85)^{*}\end{array}$ & $\begin{array}{c}.383 \\
{[1.47]} \\
(1.76)^{*}\end{array}$ \\
\hline CompInd & & & & $\begin{array}{c}-.264 \\
{[0.77]} \\
(-2.60) * * *\end{array}$ & $\begin{array}{c}-.265 \\
{[0.77]} \\
(-2.84)^{* * * *}\end{array}$ \\
\hline$Q L C H$ & & & & $\begin{array}{c}.070 \\
{[1.07]} \\
(1.90)^{*}\end{array}$ & $\begin{array}{c}.065 \\
{[1.07]} \\
(1.80)^{*}\end{array}$ \\
\hline Right & & & & $\begin{array}{c}-1.811 \\
{[.16]} \\
(-2.96)^{* * *}\end{array}$ & $\begin{array}{c}-1.903 \\
{[.15]} \\
(-3.17)^{* * *}\end{array}$ \\
\hline Pseudo $\mathrm{R}^{2}$ & .17 & .16 & .19 & .27 & .27 \\
\hline$\%$ Correct predictions & 93.08 & 92.67 & 92.64 & 93.58 & 93.37 \\
\hline No. Observations & 419 & 423 & 408 & 374 & 377 \\
\hline Failures / Programs & $29 / 39$ & $30 / 39$ & $28 / 38$ & $27 / 38$ & $28 / 39$ \\
\hline
\end{tabular}

Sources: see tables 1 and 2.

Notes:

- Odds ratios are in brackets and $t$-statistics are in parentheses;

- Significance level at which the null hypothesis is rejected: ***, $1 \%$;*, 5\%; and *, 10\%;

- Models estimated with a constant, controlling for random effects of programs. 
Table 4: Robustness Tests

\begin{tabular}{|c|c|c|c|c|c|}
\hline & 1 & 2 & 3 & 4 & 5 \\
\hline \multirow[t]{3}{*}{$\operatorname{Reer}(-1)$} & -.028 & -.018 & -.019 & -.017 & -.015 \\
\hline & {$[.97]$} & [.98] & [.98] & {$[.98]$} & {$[.98]$} \\
\hline & $(-2.78)^{* * *}$ & $(-1.72)^{* *}$ & $(-1.72)^{* *}$ & $(-1.51)$ & $(-1.28)$ \\
\hline \multirow[t]{3}{*}{$F B / G D P(-1)$} & -.143 & -.181 & -.168 & -.162 & -.202 \\
\hline & [.87] & {$[.83]$} & [.84] & {$[.85]$} & {$[.82]$} \\
\hline & $(-3.78)^{* * *}$ & $(-4.30) * * *$ & $(-4.25)^{* * *}$ & $(-4.26)^{* * *}$ & $(-4.34)^{* * *}$ \\
\hline \multirow[t]{3}{*}{$T R$} & -.022 & -.018 & -.018 & -.019 & -.017 \\
\hline & [.98] & [.98] & [.98] & [.98] & [.98] \\
\hline & $(-2.54)^{* *}$ & $(-1.96)^{* *}$ & $(-1.99)^{* *}$ & $(-2.12)^{* *}$ & $(-1.82)^{*}$ \\
\hline \multirow[t]{3}{*}{$G D P(-1)$} & -.084 & -.113 & -.122 & -.119 & -.122 \\
\hline & {$[.92]$} & {$[.90]$} & {$[.89]$} & {$[.89]$} & {$[.89]$} \\
\hline & $(-1.75)^{*}$ & $(-2.30)^{* *}$ & $(-2.59)^{* * *}$ & $(-2.55)^{* *}$ & $(-2.44)^{* *}$ \\
\hline \multirow[t]{3}{*}{ GCrises (-1) } & & & .374 & .433 & .298 \\
\hline & & & {$[1.45]$} & [1.54] & [1.35] \\
\hline & & & $(2.18)^{* *}$ & $(2.45)^{* *}$ & $(1.70)^{*}$ \\
\hline \multirow[t]{3}{*}{ Govcrise (-1) } & 2.288 & & & & \\
\hline & [9.86] & & & & \\
\hline & $(2.79) * * *$ & & & & \\
\hline \multirow[t]{3}{*}{ CabChanges (-1) } & & .670 & & & \\
\hline & & {$[1.95]$} & & & \\
\hline & & $(1.85)^{*}$ & & & \\
\hline \multirow[t]{3}{*}{ FracInd } & .243 & .147 & .324 & .255 & .410 \\
\hline & {$[1.28]$} & [1.16] & {$[1.38]$} & [1.29] & {$[1.51]$} \\
\hline & $(1.05)$ & $(.63)$ & $(1.74)^{*}$ & $(1.40)$ & $(1.79)^{*}$ \\
\hline \multirow[t]{3}{*}{ CompInd } & -.180 & -.244 & & & -.291 \\
\hline & [.84] & [.78] & & & [.75] \\
\hline & $(-2.15)^{* *}$ & $(-2.61)^{* * *}$ & & & $(-2.95)^{* * *}$ \\
\hline \multirow[t]{3}{*}{ Type } & & & 2.289 & & \\
\hline & & & [9.87] & & \\
\hline & & & $(2.57)^{* * *}$ & & \\
\hline \multirow[t]{3}{*}{ Polity $<-5$} & & & & 2.128 & \\
\hline & & & & [8.39] & \\
\hline & & & & $(2.51)^{* *}$ & \\
\hline \multirow[t]{3}{*}{$Q L C H$} & .073 & .083 & .056 & .045 & .060 \\
\hline & {$[1.08]$} & {$[1.07]$} & {$[1.06]$} & {$[1.05]$} & {$[1.06]$} \\
\hline & $(2.05)^{* *}$ & $(2.17)^{* *}$ & $(1.60)$ & $(1.28)$ & $(1.70)^{*}$ \\
\hline \multirow[t]{3}{*}{ Right } & -1.292 & -1.942 & -2.062 & -1.823 & -2.087 \\
\hline & {$[.27]$} & {$[.14]$} & {$[.13]$} & {$[.16]$} & {$[.12]$} \\
\hline & $(-2.37)^{* *}$ & $(-3.24)^{* * *}$ & $(-3.11)^{* * *}$ & $(-3.01)^{* * *}$ & $(-3.33)^{* * *}$ \\
\hline \multirow[t]{3}{*}{ Dur_Prog } & & & & & .084 \\
\hline & & & & & {$[1.09]$} \\
\hline & & & & & $(1.51)$ \\
\hline Pseudo $\mathrm{R}^{2}$ & .27 & .27 & .26 & .26 & .28 \\
\hline$\%$ Correct predictions & 93.55 & 92.84 & 93.09 & 92.83 & 93.10 \\
\hline No. Observations & 403 & 377 & 391 & 391 & 377 \\
\hline Failures / Programs & $28 / 39$ & $28 / 39$ & $29 / 39$ & $29 / 39$ & $28 / 39$ \\
\hline
\end{tabular}

Sources: see tables 1 and 2.

Notes:

- Odds ratios are in brackets and $t$-statistics are in parentheses;

- Significance level at which the null hypothesis is rejected: ***, $1 \% ; * *, 5 \%$; and *, 10\%;

- Models estimated with a constant, controlling for random effects of programs. 
Table 5: Sensitivity Analysis

\begin{tabular}{|c|c|c|c|c|c|}
\hline & \multirow{2}{*}{$\begin{array}{c}\begin{array}{c}\text { 5-year } \\
\text { Limit }\end{array} \\
\text { Major } \\
\text { Programs }\end{array}$} & \multicolumn{2}{|c|}{ 7-year Limit } & \multicolumn{2}{|c|}{ No Time Limit } \\
\hline & & $\underset{\text { Programs }}{\text { All }}$ & $\begin{array}{c}\text { Major } \\
\text { Programs }\end{array}$ & $\underset{\text { Programs }}{\text { All }}$ & $\begin{array}{c}\text { Major } \\
\text { Programs }\end{array}$ \\
\hline $\operatorname{Reer}(-1)$ & $\begin{array}{c}-.034 \\
{[.97]} \\
(-2.21)^{* *}\end{array}$ & $\begin{array}{c}-.024 \\
{[.98]} \\
(-2.10)^{* *}\end{array}$ & $\begin{array}{c}-.034 \\
{[.97]} \\
(-2.20)^{* *}\end{array}$ & $\begin{array}{c}-.023 \\
{[.98]} \\
(-2.55)^{* *}\end{array}$ & $\begin{array}{c}-.021 \\
{[.98]} \\
(-1.94)^{*}\end{array}$ \\
\hline$F B / G D P(-1)$ & $\begin{array}{c}-.190 \\
{[.83]} \\
(-1.79)^{*}\end{array}$ & $\begin{array}{c}-.188 \\
{[.83]} \\
(-4.49)^{* * *}\end{array}$ & $\begin{array}{c}-.184 \\
{[.83]} \\
(-1.73)^{*}\end{array}$ & $\begin{array}{c}-.139 \\
{[.87]} \\
(-4.03) * * *\end{array}$ & $\begin{array}{c}-.132 \\
{[.88]} \\
(-1.47)\end{array}$ \\
\hline$T R$ & $\begin{array}{c}-.013 \\
{[.99]} \\
(-1.19)\end{array}$ & $\begin{array}{c}-.019 \\
{[.98]} \\
(-2.08)^{* *}\end{array}$ & $\begin{array}{c}-.014 \\
{[.97]} \\
(-1.23)\end{array}$ & $\begin{array}{c}-.024 \\
{[.98]} \\
(-2.95)^{* * *}\end{array}$ & $\begin{array}{c}-.019 \\
{[.98]} \\
(-1.89)^{*}\end{array}$ \\
\hline$G D P(-1)$ & $\begin{array}{c}-.074 \\
{[.93]} \\
(-1.10)\end{array}$ & $\begin{array}{c}-.108 \\
{[.90]} \\
(-2.24)^{* *} \\
\end{array}$ & $\begin{array}{c}-.077 \\
{[.93]} \\
(-1.14)\end{array}$ & $\begin{array}{c}-.078 \\
{[.92]} \\
(-1.77)^{*}\end{array}$ & $\begin{array}{c}-.033 \\
{[.97]} \\
(-.54)\end{array}$ \\
\hline GCrises (-1) & $\begin{array}{c}.395 \\
{[1.48]} \\
(1.94)^{*}\end{array}$ & $\begin{array}{c}.282 \\
{[1.33]} \\
(1.73)^{*}\end{array}$ & $\begin{array}{c}.330 \\
{[1.39]} \\
(1.72)^{*}\end{array}$ & & \\
\hline Govcrise (-1) & & & & $\begin{array}{c}2.093 \\
{[8.11]} \\
(2.67)^{* * *}\end{array}$ & $\begin{array}{c}1.999 \\
{[7.38]} \\
(2.00)^{* *}\end{array}$ \\
\hline FracInd & $\begin{array}{c}.462 \\
{[1.59]} \\
(1.81)^{*}\end{array}$ & $\begin{array}{c}.363 \\
{[1.44]} \\
(1.59)\end{array}$ & $\begin{array}{c}.470 \\
{[1.60]} \\
(1.79)^{*}\end{array}$ & $\begin{array}{l}-.031 \\
{[.97]} \\
(-.12)\end{array}$ & $\begin{array}{c}.024 \\
{[1.02]} \\
(.09)\end{array}$ \\
\hline CompInd & $\begin{array}{c}-.326 \\
{[.72]} \\
(-2.65)^{* * *}\end{array}$ & $\begin{array}{c}-.290 \\
{[.75]} \\
(-3.05)^{* * *}\end{array}$ & $\begin{array}{c}-.360 \\
{[.70]} \\
(-2.81)^{* * *}\end{array}$ & $\begin{array}{c}-.105 \\
{[.90]} \\
(-1.31)\end{array}$ & $\begin{array}{c}-.129 \\
{[.88]} \\
(-1.37)\end{array}$ \\
\hline$Q L C H$ & $\begin{array}{c}.030 \\
{[1.03]} \\
(.58)\end{array}$ & $\begin{array}{c}.066 \\
{[1.07]} \\
(1.89)^{*}\end{array}$ & $\begin{array}{c}.022 \\
{[1.02]} \\
(.44)\end{array}$ & $\begin{array}{c}.053 \\
{[1.05]} \\
(1.60)\end{array}$ & $\begin{array}{l}-.013 \\
{[.99]} \\
(-.26)\end{array}$ \\
\hline Right & $\begin{array}{c}-2.033 \\
{[.13]} \\
(-1.97)^{* *}\end{array}$ & $\begin{array}{c}-2.112 \\
{[.12]} \\
(-3.46)^{* * *}\end{array}$ & $\begin{array}{c}-2.314 \\
{[.10]} \\
(-2.19)^{* *}\end{array}$ & $\begin{array}{c}-.941 \\
{[.39]} \\
(-1.97)^{* *}\end{array}$ & $\begin{array}{l}-.471 \\
{[.62]} \\
(-.62)\end{array}$ \\
\hline Pseudo $\mathrm{R}^{2}$ & .21 & .29 & .22 & .23 & .15 \\
\hline$\%$ Correct predictions & 95.65 & 93.51 & 96.13 & 94.32 & 96.36 \\
\hline No. Observations & 299 & 416 & 336 & 475 & 385 \\
\hline Failures / Programs & $13 / 23$ & $29 / 39$ & $13 / 23$ & $31 / 39$ & $15 / 23$ \\
\hline
\end{tabular}

Sources: see tables 1 and 2.

Notes:

- Odds ratios are in brackets and $t$-statistics are in parentheses;

- Significance level at which the null hypothesis is rejected: ***, 1\%; **, 5\%; and *, 10\%;

- Models estimated with a constant, controlling for random effects of programs. 